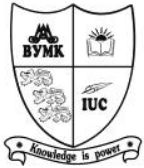

European Journal of Tourism Research

http://ejtr.vumk.eu

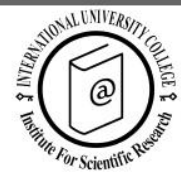

\title{
Consumer choices of international mountaineering holiday: A perspective of Slovak mountaineering market towards Slovak tourism providers
}

\author{
J. Janockova ${ }^{1}$, J. Jablonska ${ }^{1}$ and G. M. Timcak ${ }^{1 *}$
}

Received: 11/08/2011 Accepted: 23/04/2012

\footnotetext{
${ }^{1}$ Institute of Geotourism, BERG Faculty, Technical University Košice, Slovakia

* Corresponding author; e-mail: Gejza.Timcak@tuke.sk
}

\begin{abstract}
The main purpose of this study was to critically analyze consumer choices of Slovak mountaineers for purchasing international mountaineering holiday from Slovak outbound travel agencies/touroperators. To increase the probability of the respondents' geographic, age and gender varieties, qualitative questionnaires were distributed among 80 respondents using the method of cluster sampling. The preferences of mountaineering holiday arrangement of the analysed market were found to be through personal communication with Slovak travel intermediaries, which was perceived more safe and time-saving then independent purchase or/and purchase through international travel intermediaries. An individually tailored holiday was preferred as it provides safety and simultaneously satisfies the desired elements of freedom and independence. The main issues regarding the provided services by the Slovak outbound travel agencies/tour-operators have been related to lack of mountaineering expertise and an inappropriate service delivery.
\end{abstract}

(c) 2012 International University College. All rights reserved

Keywords: mountaineering, consumer choice, tour operators, travel agencies, Slovakia

Citation: Janockova, J., J. Jablonska, G. Timcak (2012) Consumer choices of international mountaineering holiday: A perspective of Slovak mountaineering market towards Slovak tourism providers. European Journal of Tourism Research 5(2), pp. 153-165

\section{Introduction}

Mountaineering on the territory of present day Slovakia ${ }^{1}$ started in the $17^{\text {th }}$ Century, when the first known climbing in the High Tatra Mountains was done by D. Fröhlich (in 1639). In 1871 the Hungarian Carpathian Club was established, which started a new chapter of climbing in the Tatra Mountains. Services to mountaineers started by lending climbing gears by local villagers in the $17^{\text {th }}$ Century and then by building manned mountaineering huts in the $19^{\text {th }}$ Century (Bucsek 1973). In 1921 the JAMES Mountaineering Club was established in the High Tatra Resort, which - excluding the period of post-war communist regime - up to now supports Slovakian mountaineering activities (JAMES 2001, History 2010). It is a member of the UIAA. Since 1924 the 
community of Slovakian climbers was organized within Sports Clubs, which managed the training of mountaineers (Bartunkova 2008). Prior to 1989 expeditions to international mountain areas were accessible only to few. After 1989 Slovakian mountaineers started to explore all the available mountain ranges and thus the travel industry developed programs for this demand. Mountaineering is an increasingly popular tourism activity as it relates with modern consumers' main holiday drives of tranquillity, scenic beauty, also danger and challenges (Mountain Agenda, 1999; Weaver and Lawton, 2006; Faullant, Matzler, Mooradian, 2011). The way mountaineering holidays are being packaged are influenced by increasing marketing pressure that encourages mountaineers to turn to travel providers (Goossens, 2000) and by the modern lifestyle that depends on services. Independence in mountaineering tourist travel is becoming uncommon (Swarbrooke and Horner, 2007); commercialization of mountaineering limits the control experts traditionally had over the domain. This is possible as advancement in the field of sensu lato mountaineering enables touring even without prior mountaineering experience or training in similar mountain environments (Beedie and Hudson, 2003; Schejbal 2009). Nevertheless, organising the tour independently instead of following the 'system', can enhance the adventurous experience in a holiday (Swarbrooke, Beard, Leckie and Pomfret, 2003; Lengyel, 2004).

The mountaineering related research is at its beginnings in Slovakian context and this article aims at critically analyzing the consumer choices of Slovak mountaineers for purchase of an international mountaineering holiday from Slovak outbound travel agencies/touroperators. The aim is to be met by objectives of firstly, analyze how the criteria of customers for an international mountaineering holiday purchase are perceived to be met by the Slovak outbound travel agencies and touroperators. Secondly, it was sought to understand the issues leading to preferences of a particular holiday arrangement (independent purchase or purchase through Slovak or international travel intermediaries) (Janockova 2010).

\section{Literature review}

The definition of mountaineering varies in the literature that deals with its theory due to a recognition that it consists of a number of activities. Most frequently it is referred to in a broader context as a process including a range of activities taking place in mountainous environment (Mountaineering Development Sub Group, Connally, 2005; Millington et al., 2001). This article relates to Gallegos (2006), who defines mountaineering as 'climbing mountains', which 'involves hiking as well as technical climbing abilities to climb from the base of the mountain to the peak and down again, over a variety of surfaces'.

Mountaineering tourism is given an increasing academic attention, which is focused on markets in North America (e.g. Sung, 2004; Buckley, 2006; Sung, Morrison and O'Leary, 1997, 2000), Western Europe (e.g. Greenwood and Yeoman, 2007, Icelandic Tourist Board, 2010) and Australia (e.g. Tourism Research Australia, 2007, Otago Institute of Sport and Adventure, 2008). Despite a growing offer of outbound mountaineering holiday by the Slovak travel agencies/tour-operators, there is a lack of research to support successful marketing strategies for businesses serving the centraland east-European markets. Specifying the consumer choices for travel providers and their services could provide clues regarding best appeal and satisfaction regarding the target market by the Slovak outbound travel agencies/tour-operators.

From a marketing point of view, it is essential to clarify the target market client decision-making process in relation to the provided marketing stimuli (Kotler, Bowen and Makens, 2006). The stimuli for mountaineering holiday abroad provided by Slovak outbound travel agencies/tour-operators can be analyzed e.g. through the offered product as an essential part of the marketing activity (Holloway, 2004; Kotler and Armstrong, 2004). Generally, the offer of tourism products is related to five basic components: the destination attractions and environment, destination facilities and services, accessibility of the destination, images and perceptions of the destination and retail price (e.g. Middleton, Fyall, Morgan and Ranchhod, 2009). For an improvement of marketing 
communication between supply and demand, in our investigation, the researched subjects were invited to express perceptions of the importance of the mentioned tourism components and the sufficiency of their inclusion in the offer of Slovak travel agencies/tour-operators.

Proceeding from the marketing stimuli to a purchase decision includes evaluation of the given information according to criteria of buyer perceptions, a term explained by Middleton and Clarke (2005: 80) as 'a function of attitudes, motivations, experience and learning'. Insight into these should improve the marketing communication (Middleton and Clarke, 2005), which needs to be coordinated to provide a unified message communicating the intangible part of services (Grove, Carlson and Dorsch, 2002). Yet, there is a great complexity of perceptions and characteristics, which are part of the 'black box' within which the potential customer evaluates possibilities and acts upon the provided marketing and other stimuli (Kotler, Bowen and Makens, 2006). It is therefore necessary to analyse the resulting actions for discovering a rationale behind the buyer behaviour (Middleton, Fyall, Morgan and Ranchhod, 2009). Once the choice or problem is specified in the researched process, the attitudes of the market can be understood (Uysal and Noe, 2002). Through this knowledge, we identify the buyer behaviour patterns of Slovak mountaineers before and during the booking process according to a framework given by Middleton, Fyall, Morgan and Ranchhod (2009: 107). The framework identifies four specific characteristics for the pre-booking stage, namely: previous usage/experience/expectation, loyal/infrequent user, awareness/use of brochures/use of Internet, sources of travel information used and length of booking time before use. The booking process can - according to this framework consist of package/independent arrangements, via central reservation office or via a website, booking directly at the producer and sale/discounts/special offers. By researching the preferences of holiday arrangement, the question of the desired level of independence of mountaineers from the tourism supply side can be understood for the analysed market. For international mountaineering markets, there are various stands towards the discussion on the questions of safety assurance and other aspects of the independent arrangements. Mountaineers still tend to incline towards individual booking, leaving out the travel intermediaries (Beedie and Hudson, 2003; Swarbrooke, Beard, Leckie and Pomfret, 2003). However, turning to travel intermediaries is increasingly stimulated by the perceptions of time-saving value, as the market is characterized as educated, demanding and having a busy lifestyle (Goossens, 2000; Pomfret, 2006). The framework mentioned by Middleton et al. (2009) also covers stages of "in use/consumption patterns" and "after use buyer characteristics", and this study shows the first two stages considered by the authors as a priority in identifying the booking patterns of the analyzed market. While the characteristics are not all-inclusive, the framework is argued to cover significant aspects of market needs with implications for most tourism businesses (Middleton, Fyall, Morgan and Ranchhod, 2009; Kotler, Bowen and Makens, 2006).

\section{Methodology}

Mountaineers are characterized by certain similarities in travel behaviour, yet they have diverse standpoints towards mountaineering commercialization and communication with travel intermediaries. Therefore in view of such complex research subject, a quasiphenomenological stand with a qualitative approach to research enabled an individual and a more in-depth exploration of the perspectives of the researched population (Ritchie, Burns and Palmer, 2005). Also, adventure tourism, including mountaineering, has yet a relatively unexplored research and theory knowledge base (Sung, 2004, Swarbrooke and Horner, 2007). Therefore the employed strategy is seen as suitable because it is used within academic research when researching a phenomenon not yet explored in-depth (Finn, Eliott-White and Walton, 2000). This, to a certain extent, necessarily influences the data accuracy (Jennings, 2005; Ritchie, Burns and Palmer, 2005), therefore this study forms a base for other researches aimed at clarification of the precision of the findings.

The questionnaires as a qualitative research instrument inevitably limit the depth of obtained 
data, yet a less-structured design is useful for exploring qualitative data from a wider sample than is possible by interviews (Pratt, 2007). The questionnaires were structured into three parts in order to find the perceptions of Slovak mountaineers towards the outbound travel agencies/tour-operators offering mountaineerring holidays. The first part analysed the perceived importance of specific elements to be included in an international mountaineering tourism product. These were structured according to the five basic components of tourism products, as discussed above in the literature review. The second part of the questionnaires aimed at understanding the views of respondents as to how the different product criteria are perceived to be reflected in the offer of Slovak outbound travel agencies/tour-operators. Finally, Slovak mountaineers' buyer behaviour before and during the holiday booking process was investigated according to the framework given by Middleton, Fyall, Morgan and Ranchhod (2009), as mentioned in the literature review. This part also included questions on the attitudes of respondents towards independence from the tourism supply side during the arrangements and the travel.

The questionnaire (Appendix A) was designed to collect two distinct types of research data quantitative and qualitative. The researched elements seen as clear and measurable were designed in form of closed-end questions (e.g. socio-demographic data, years of mountaineering practice). A five point importance scale was used to measure the following criteria for purchase of international mountaineering holiday: importance of face to face communication as well as time and convenience factors when organising a holiday (appendix A, question No.5). The qualitative information was collected through option tick boxes, the choice of which was to be explained further by the respondent (see appendix A, e.g. questions 2, 3). Such combination of openended and closed-ended questions provides the qualitative information with structure, and possibly explores additional relationships among the data (Pratt, 2007). Other qualitative data seen as complex (appendix A, e.g. questions No. 8, 9) were designed as open- ended questions in attempt to understand perceptions of the researched market, and also of the offer of tourism supply side (Middleton, Fyall, Morgan and Ranchhod, 2009).

The study sought to draw a representative sample of the analyzed population, which consisted of Slovak outbound tourists having mountaineering as their primary holiday objective. Cluster sampling as a type of probability sampling was selected to increase the probability of the respondents' geographic, age and gender varieties (see StatTrek.com). Considering also time- and cost- efficiency, these were the main aspects to outweigh the lesser precision of cluster sampling in comparison with other probability sampling methods (Trochim, 2006).

The used sampling method enabled to collect data from respondents of various age groups, mountaineering experience, education and income levels. Specification of sociodemographic characteristics of the respondents aimed at identification of their relationships with the identified consumer choices and perspectives (Finn, Elliott-White and Walton, 2000). However, it has to be noted that the aim of the investigation was to understand the consumer preference patterns of the analyzed population from an individual perspective, thus any relationship based on the number of respondents and their socio-demographics are considered - due to a limited sample - as of indicative character rather than being completely valid (Auerbach \& Silverstein, 2003). One of the possible constraint to generalization of the findings stems from an insufficient age variation among the respondents (over half of the sample consisted of respondents with up to 25 years of age). An exact determination of the possible bias was not possible, as there is no central register of mountaineers and not every mountaineer is a registered one.

Because it was impossible to collect a geographically comprehensive research sample, three locations in High Tatra Mountains, which is the most challenging and simultaneously most visited mountaineering area in Slovakia, were chosen for collecting 


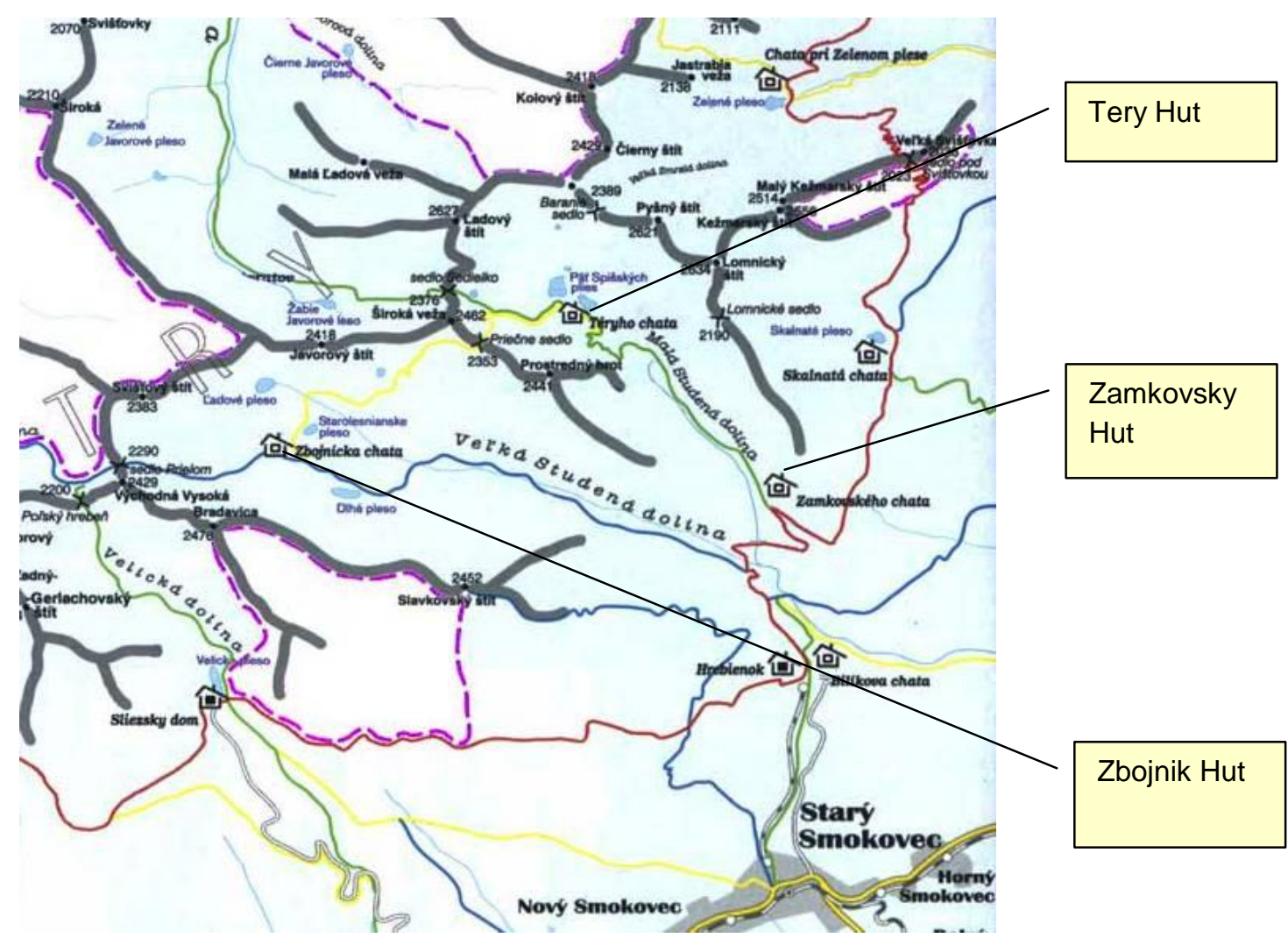

Figure 1. Sketch of the studied area and survey localities

data for the questionnaires. Localities around Tery hut, Zamkovsky hut and Zbojnik hut were chosen for this purpose (Figure 1). These are high altitude areas and access-points to the climbing routes within the area (see http://www.summitpost.org/high-tatras-vysoktatry/154185).

Altogether 80 questionnaires were given out and 23 to 25 questionnaires were distributed by the first author within one day in areas around the huts at each of the locations. Handing out questionnaire in high altitudes (around $2000 \mathrm{~m}$ above sea level) necessitates ascent to this altitude by foot and it needs also good weather conditions. The response rate for the questionnaires was 100 percent.

The primary research within the study was carried out in accordance with ethical research guidelines of Leeds Metropolitan University (available from the website of http://skillsforlearning.leedsmet.ac.uk). Prior to the interview every respondent was given an information sheet explaining the background of the researched topic along with the ethical issues of the research - rights of the respondent, anonymity and data protection.

As both quantitative and qualitative data were collected, two approaches to data analyses were used. To facilitate cross tabulation, the quantitative data obtained from closed-end questions (e.g. sociodemographic characteristics such as age variation among the respondents) and questions based on importance scales (e.g. aspects of organizing holidays personally via a travel agency/tour operator see Appendix A, question 5) were analyzed by the SPSS analytical software (information and download available from www.spss.com). The relationship between the quantitative data and the provided qualitative explanation was compared by evaluating frequency of expressed elements in the responses (for instance words such as 
freedom), using the same software. Such process of categorizing data is a frequently used method for analyzing qualitative data, as it explores also a relationship- and analyzes the fit between the obtained data and theory (Jennings, 2005; Finn, Elliott-White and Walton, 2000; Neuman, 1997; Ritchie, Peter Burns and Palmer, 2005).

\section{Data analysis and discussion}

Unlike the findings for international trends of an independent holiday arrangement (Beedie and Hudson, 2003; Swarbrooke, Beard, Leckie and Pomfret, 2003), for the analysed market it was found that personal communication with travel intermediaries is of significant importance in the booking process. Throughout the holiday arrangement, several factors were found to influence the communication between Slovak mountaineers and travel intermediaries. The issues were investigated using an importance scale of face-to-face environment when booking a holiday and this was extended by further comments given throughout the questionnaire. From the 65 responses to the question, $38.5 \%$ of respondents indicated a very high significance and $24.6 \%$ of respondents indicated a high significance of direct communication. The preferences were linked to domestic travel arrangement $(n=49$ or $61 \%$ of respondents prefer such holiday arrangement, while $n=7 \quad(8.8 \%)$ did not respond to the question). The preferences did not interrelate with mountaineering experience given by stating the years of active mountaineering and the mentioned option had a leading preference in all mountaineering experience categories.

The value of direct communication linked to the provided perceptions is a term explained by Middleton and Clarke (2005: 80) as 'a function of attitudes, motivations, experience and learning'. It was noted throughout the responses that personal communication with Slovak travel intermediaries is by a strong majority related to notions of safety $(n=20$ or $25 \%$ ). At a much smaller rate, the perceived advantage is considered in terms of timeeffectiveness $(n=13$ or $16.3 \%)$ and convenience $(n=11$ or $13.8 \%)$. Safety, time and convenience represented the main expectations in relation to a holiday purchase made in person. The majority of the respondents expressed satisfaction with Slovak travel intermediaries in dealing with travel arrangements such as visa or climbing allowances. These were perceived as formalities requiring investment of unnecessary energy and taking the focus away from the experience of mountaineering. Thus help with these arrangements were - according to the comments - seen as convenient and of timesaving value. However, issues arose in service expectations which were insufficiently met by the Slovak outbound travel agencies/touroperators, what in turn resulted in a certain aversion towards personal communication with tourism providers. The responses suggested a need for improvement of the service delivery by the staff at selling points as well as by staff present at the destination. The issue was raised through the given comments, all of which expressed dissatisfaction. For instance, a respondent stated on the issue: "I think their offer (mountaineering holiday offer by Slovak outbound travel agencies/tour-operators) is improving. However, I think the problem is in the way the service is being delivered. Their attitude does not satisfy a mountaineer ... you can see, it is all about their business and they do not care about your needs". Another respondent commented: "I know from friends that they act as if it was obvious that they have a better (mountaineering) experience. People do not go to them, however, to get a lecture". Although these are individual opinions, it can be noted that there is a reflection of the mountaineering attitude including tolerance and responsibility from the service providers. Similar perceptions were stated regarding Slovak mountaineering guides accompanying the tourists at the holiday destinations, which can be considered to be a significant factor for choosing or not choosing a pre-designed mountaineering holiday. While from the provided responses, the satisfaction rate with the guides was significantly better than with staff at the selling points (18 respondents were dissatisfied, 15 were satisfied), again, suggestions were given regarding areas which need improvement. For instance, a respondent stated: "They (Slovak mountaineering guides) are impatient, have a rude attitude towards clients and locals, they underestimate clients". 
Another respondent reflected: "It is being said that they (Slovak mountaineering guides) are impatient, lack expertise, and are not professionals". It has to be noted that the stated perceptions do not necessarily stem from a direct experience.

Because all these perceptions should be considered as the evaluation criteria of alternatives in the buyer decision process (Middleton and Clarke, 2005; Horner and Swarbrooke, 2005), the obtained answers should motivate Slovak outbound travel agencies/tour-operators to improve the intangible part of services as expertise, to deliver excellent customer service and responsibility of their staff; as these were the most frequently mentioned conflict areas. However, it would seem useful to gain a deeper insight into the questions of expertise than the one specified through the responses, as some responses did not clearly indicate whether the expertise concerned mountaineering or travel arrangement aspects, and what qualification and experience would satisfy their needs.

Together with a stated lack of expertise, at the same time a perceived cheaper price was the main reason for considering the services of international travel agency or tour operator. Although the majority of the respondents showed dissatisfaction with the price of holiday offer by Slovak outbound travel agencies/touroperators, and viewed other forms of booking as cheaper, the considerations of safety and time outweighed preferences of other booking options. This stresses safety as priority to a possibly wider offer and better quality of international travel agencies/ tour operators and to the situational factors such as time, or finance.

Other perceived obstacles to booking through international travel intermediaries related mostly to language barriers ( $n=13$ or $16.3 \%$ ) and the possible difficulties linked to an 'unknown system'. One respondent expressed her worries regarding international travel arrangement: "I know it could be more valuable, but if something goes wrong, here (in Slovakia) I know where to turn to, it's (the possible added value by international travel suppliers) not worth the worries".
According to our findings there seems to be a rising tendency of Internet booking among younger travellers. Key reasons for independent booking were the maximized feeling of no restrictions related to notions of freedom and independence, aspects of which exceeded aspects of safety in the response of $37.5 \%$ of respondents $(n=30)$. Besides being major drives for participating in a mountaineering holiday, these aspects also represented self-reflection of the respondents by referring to themselves as independent, not liking any kind of restriction. The gradual assurance of safety and other positive aspects of the independent arrangements reflect in the consumer trends of western markets which are becoming more experienced in independence, flexibility and control over their purchase choices (Swarbrooke, Beard, Leckie and Pomfret, 2003). As the analyses of our research population also indicate younger markets inclining to independent purchase alternatives, for Slovak outbound travel agencies/tour operators this would indicate the necessity to focus particularly on younger markets and capture the perceived value of Internet in the presented marketing communication.

From the above discussion, significance of two contrasting needs of the analysed market can be identified; a desire for intensive holiday experience accompanied by the feeling of freedom and no restrictions, yet within a frame of a safe travel arrangement as reflected by the mentioned perceptions. Thus the preferred option was an individually tailored travel arrangement booked in person with a Slovak travel agency/tour operator (a favoured form of travel arrangement by $35 \%$ of respondents, $n=$ 28). This form of travel arrangement was referred to as safe, while adding to the adventure aspect of the overall holiday experience.

Insights into the product area preferences were provided by the respondents in their reflection on the mountaineering tourism offer by Slovak travel agencies/tour-operators. The focus of the agencies on popular destinations with well established mountaineering routes was prevailingly a subject of perceived dissatisfaction $(n=32$ or $40 \%$ dissatisfied 
respondents compared to $\mathrm{n}=15$ or $18.8 \%$ who expressed satisfaction). Several respondents noted that the travel agencies offered a wide set of routes in neighbouring countries as opposed to more distant countries. The respondents further commented on the issue of stated unwillingness to do mountaineering in overcrowded and over-commercialized routes. It was clear from analyzing the responses that the mountaineering location is a significant criterion to mountaineers, and it was found that the destination alone looses the value when shared by too many tourists. Thus even the locations perceived traditionally as most desired mountaineering destinations, were perceived as over-commercialized by the responses. Through a certain aversion to such destinations, ideas pointed towards less well known localities, which are perceived as more unique destinations. Another notable issue that arose from the comments was that despite the desire to discover less popular places, the respondents felt insecure to visit such places without backup from the domestic tourism supply side. The approach of Slovak travel providers of focusing on established routes was perceived as to lower the adventurous feel of the holiday experience.

A strong link was noted among the perceived experience of adventure, authenticity and the mountaineering possibilities of the destination. From the number of respondents who expressed dissatisfaction with the available offer of mountaineering activities $(n=26$ or $32.5 \%$ compared to satisfaction response rate of $n=12$ or $15 \%$ ), a majority noted that this is due to lack of tourism offer in the area of greater mountaineering difficulty levels. It is interesting to note the accent on improvement of skills as a desirable holiday outcome. Explanation can be provided for instance by the following comment made by a respondent: 'The offer of our travel agencies does not stagnate but I would welcome an offer that would encourage me to push my (mountaineering skill) limits further'. Regarding the nonmountaineering activities at the destination, 21 of the respondents $(26.3 \%)$ showed satisfaction, while 18 (22.5\%) showed dissatisfaction with the current offer. From the further comments made on the issue (provided by $n=40$ or $50 \%$ ), it was found that the other activities are secondary in importance to mountaineering, yet the respondents inclined to the idea of activities that would widen their holiday experience through knowing the destination better. Specific ideas given by a majority of respondents related to interest in local culture. From data analyses a desire for more opportunities to communicate with the locals and for gaining knowledge about their usual ways of life was noted. Taking part in festivals and other cultural occasions was welcomed. While local culture was a frequently raised issue, the perspectives varied significantly. Several respondents raised the issue that traditional ways of life were seen as diminishing from the visited mountain locations, and as these are now becoming commercialized, no point was seen in involving in local life. This negative statement stressed the aversion to locals which see tourists only as a source of income.

The satisfaction rate with the supplementary activities within destination facilities and services was $26.3 \%$ satisfied and $25 \%$ for the dissatisfied respondents. However, further insight into this area was limited by the low number of comments provided. There was a noted indication of a demand for higher rate facilities, in particular regarding accommodation at the mountaineering access points. For example, a respondent stated: "The facilities and services in the base locations could have higher standards. When I come down from a climb I want to enjoy the luxury of these services. The offer should be widened, although most people probably prefer lower price not higher quality." Another respondent reacted: "More distinction is needed regarding these (destination facilities and services). Transport and base camp facilities should be of a higher level, during the climb (the facilities are) obviously basic." This is interesting in terms of preferring quality of services to consideration of price.

The questionnaire further invited comments on the product area of transport to and at the destination, again through a reflection on the Slovak outbound travel agencies/touroperators. It was found from the response rate 
that prevailingly, the organisation of transport has satisfactory quality $(n=32$ or $40 \%$ showed satisfaction, $n=13$, or $16.3 \%$ expressed dissatisfaction). The observations of respondents on the accessibility of the destinations were mostly welcoming, whilst valuing also the available options of individual transport.

The results of this survey indicate that in the mountaineering part of adventure tourism from the point of view of the sampled Slovakian mountaineering population have similar needs as indicated in the literature (e.g. Hudson 2003). Further research would be needed to evaluate the differences between the needs, preferences and booking habits of mountaineers in other countries.

\section{Conclusion}

Our analysis indicates that the Slovak mountaineering market prefers a tailored mountaineering holiday booked in person from Slovak travel agency/operator despite the fact that the international travel travel agencies/tour-operators were seen as providing better value in terms of mountaineering expertise and a wider holiday offer. The aspects of safety, convenience and language barriers made other holiday arrangements a second choice to booking in person from Slovak outbound travel agencies/tour-operators. It is questionable to what extent the international mountaineering trend of independent Internet booking, either through travel intermediary or directly with tourism product suppliers will be followed by the Slovak market, given the availability of ever advancing technology and opportunities of the market.

Several service areas of Slovak outbound travel agencies/tour-operators were referred to as dissatisfactory. The main areas in need of improvement were the service delivery aspects related to communication and mountaineering expertise. Additionally, the destination offer was referred to as limited to 'popular' locations, with a wider choice of mountaineering routes only in the neighbouring countries. Interrelated with the destination offer, the mountaineering activities were considered significantly limited to a less demanding mountaineering. This suggests the need of broadening the offer with possibilities of less commercialised routes and advanced mountaineering opportunities, as well as improving human resources development of service providers so that they can provide high quality customer service.

For contextualising these results with the habits of an international community of climbers, further research would be needed as most of the available research results were not based on high altitude field work.

\section{Endnotes:}

${ }^{1}$ Up to 1918 the territory of present day Slovakia formed a part of the Austro-Hungarian Monarchy

2 JAMES stands for: Idealism, Alpinism, Morality, Eugenics, Solidarity

${ }^{3}$ UIAA stands for International Mountaneering and Climbing Federation

\section{References}

Auerbach, C. F. \& Silverstein, L. B. (2003). Qualitative data: an introduction to coding and analysis. New York University Press.

Bartunkova A. (2008) Mountaineering. Sports and physical culture archives, 153, (20), 1-15 http://www.nm.cz/admin/files/HM/downl oad/novod_dejiny/telesna_vychova/hor olezectvi.pdf (Accessed 20 November, 2011).

Beedie, P. \& Hudson, S. (2003). Emergence of mountain-based adventure tourism. Annals of Tourism Research, 30(3), 625-643.

Bucsek, H. (1973). A Magyar hegymászás története 1873-ig, Hegymászó Hiradó, (vol. not given), (3), 3-11, URL: http://www.fsz.bme.hu/mtsz/mhk/csarn ok/b/bucsek/bhtortenet.htm, (Accessed $20^{\text {th }}$ April, 2012).

Connally, C. (2005). Mountaineering handbook: Modern tools and techniques that will take you to the top. Ragged Mountain Press, UK.

Finn, M., Eliott-White, M. \& Walton, M. (2000). Tourism and leisure research methods: data collection, analyses and interpretation. Harlow, Longman.

Faullant R., Matzler K. \& Mooradian T. A. (2011). Personality, basic emotions and satisfaction: Primary emotions in 
the mountaineering experience. Tourism management, 32(6), 14231430.

Gallegos, J. (2006) What Is Mountaineering. URL:

http://extremesports.suite101.com/articl e.cfm/what_is_mountaineering_\#ixzz0 XKN8CYD9 (Accessed $20^{\text {th }}$ November, 2009).

Goossens C. (2000). Tourism information and pleasure motivation. Annals of Tourism Research, 27(2), 301-321.

Greenwood, C. \& Yeoman, I. (2007). What will activity and adventure tourism look like in 2015? URL: http://www.visitscotland. org/adventure tourism forecast_march 07.pdf (Accessed $20^{\text {th }}$ May, 2009).

Grove, S. J., Carlson, L. \& Dorsch, M. J. (2002). Addressing services' intangibility through integrated marketing communication: an exploratory study. Journal of Services Marketing, 16(5), 393-411.

History (2010). História slovenského horolezectva. URL: http://www. sportency.sk/encyclopedy/?q=content/ hist\%C3\%B3ria-slovensk\%C3\%A9hohorolezectva, (Accessed 20 ${ }^{\text {th }}$ April, 2011).

Holloway, J. C. (2004). Marketing for tourism. Prentice Hall/Pearson Education Ltd.

Horner, S. \& Swarbrooke, J. (2005). Leisure Marketing: A global perspective. Oxford: Butterworth-Heinemann.

Icelandic Tourist board (2010). Official website. URL: $\quad$ http://www.icelandvisitor.com (Accessed 20 ${ }^{\text {th }}$ May, 2010).

JAMES (2001). História výškového horolezectva. URL: http://www.james.sk/articles.asp?pagei $\mathrm{d}=19$ \&id_dependency $=2719$,

(Accessed 20 ${ }^{\text {th }}$ April, 2011).

Janockova, J. (2010). Consumer choices of international mountaineering holiday: $A$ perspective of Slovak mountaineering market towards Slovak tourism providers. MSc Thesis. Leslie Silver International Faculty, Leeds Metropolitan University, United Kingdom.
Jennings, G. (2005). Tourism research methods: integrating theory with practice. Wallington: CABI.

Kotler, P. \& Armstrong G. (2004) Principles of marketing. Prentice Hall

Kotler, P., Bowen, J. \& Makens, J. (2006). Marketing for hospitality and tourism. New Jersey: Pearson Education. $4^{\text {th }}$ ed.

Lengyel, M. (2004). A general theory of tourism. KIT Budapest (in Hungarian).

Middleton, V. T. C. \& Clarke, J. (2005). Marketing in travel and tourism. Oxford: Elsevier Butterworth-Heinemann

Middleton, V. T. C., Fyall, A., Morgan, M. \& Ranchhod, A. (2009). Marketing in travel and tourism. $4^{\text {th }}$ ed. Elsevier Ltd..

Millington, K., Locke T. \& Locke A. (2001). Adventure travel. Travel \& Tourism Analyst 4, 65-98.

Price, M., Wachs, T. \& Byers E. (eds.) (1999) Mountain agenda. Mountains of the world - tourism and sustainable mountain development. CDE, Institute of Geography, Bern.

Mountaineering Development Sub Group (MDSG) Terms of Reference. URL: http://www.mountaineeringscotland.org.uk/council/mdsg_tor.pdf (Accessed $20^{\text {th }}$ December, 2009).

Neuman, W. L. (1997). Social research methods: qualitative and quantitative approaches. London: Allyn and Bacon.

Otago Institute of Sport and Adventure (2008). Adventure Tourism. URL: http://www.slideshare.net/hillarypjenkin s/intro-to-adventure-tourism-op-09presentation (Accessed $20^{\text {th }}$ May, 2009).

Pomfret, G. (2006). Mountaineering adventure tourists: A conceptual framework for research. Tourism Management, 27(1), 113-123.

Pratt, N. (2007). Using questionnaires in education. Faculty of Education, University of Plymouth. URL: http://www.edu.plymouth.ac.uk/resined/ QUESTS/index.htm (Accessed 20 ${ }^{\text {th }}$ November, 2009).

Ritchie, B. W., Burns, P. M. \& Palmer, C. A. (2005). Tourism research methods: 
integrating theory with practice. Swarbrooke, J. \& Horner, S. (2007). Consumer Wallington: CABI. behaviour in tourism. Oxford: Elsevier Ltd.

Schejbal, C. (2009). Tourism logistics. Prerov: Elan (in Czech).

StatTrek.com (Accessed $20^{\text {th }}$ November, 2011).

Sung, H. (2004). Classification of adventure travellers: behavior, decision making, and target markets. Journal of Travel Research, 42(4), 343-356.

Sung, H., Morrison A., \& O'Leary, J. (1997). Definition of adventure travel: conceptual framework for empirical application from the providers' perspective. Asia-Pacific Journal of Tourism Research, 1(2), 47-67.

Sung, H., Morrison A., \& O'Leary, J. (2000). Segmenting the adventure travel market by activities. Journal of Travel and Tourism Marketing, 9(3), 1-20.

Swarbrooke, J., Beard, C., Leckie, S. \&

Tourism Research Australia (2007). Victoria adventure tourism market profile year ending December 2007. URL: http://www.tourism.vic.gov.au/marketin $\mathrm{g} /$ marketing/market-segments (Accessed 20 ${ }^{\text {th }}$ May, 2009).

Trochim, W. M. K. (2001). Research methods knowledge base. Ohio: Atomic Dog.

Uysal, M. \& Noe, P. F. (2002). Satisfaction in outdoor recreation and tourism settings. In Laws, E. (ed.) Tourism marketing: quality and service management perspectives. Continuum, United Kingdom.

Weaver, D. B. \& Lawton, L. (2006). Tourism management. J. Wiley \& Sons. Pomfret, G. (2003). Adventure tourism: The new frontier. Oxford: Elsevier. 
APPENDIX A.

The questionnaire. (The full version of this questionnaire is available from Leeds Metropolitan University)

\section{Approximately how long do you practice mountaineering?}
( ) less than 3 years
() 5-3 years
() 9-6 years
( ) $15-10$ years
( ) More than 15 years

2. Did you ever travel internationally for the purpose of a mountaineering activity?

( ) Yes- within the last three years.

( ) Yes, but not in the last three years - Please specify the reasons which you consider as most important as why you did not travel for such purpose in the last three years:

( ) No, but I considered it - Please specify the reasons which you consider were most important for not travelling for such purpose.

3. Please comment on WHY you would or would not consider the choices shown below when purchasing an international mountaineering holiday.
A. Booking your travel through a Slovak travel agency or tour operator:
( ) You would consider
() You would not consider
Please specify why

B. Booking your travel through international travel agency or tour operator:
( ) You would consider
( ) You would not consider
Please specify why

C. Making a travel arrangement independently of tourism intermediaries:

( ) You would consider

( ) You would not consider

Please specify why
4. Which form of travel arrangement would you consider most and why?
164

( ) Package arrangement personally via reservation office
( ) Package arrangement via website
( ) Independent (Tailored) arrangement personally via reservation office
( ) Independent (Tailored) arrangement via website
( ) Arrangement directly with suppliers

Please provide any comments on giving this option priority among the other arrangements.

5. How important do you consider the following aspects when organizing your holiday personally via a travel agency/tour operator? Please rate from 1 to 10 according to level of importance ( 1 being least important 10 being most important)

( ) Face to face communication environment

( ) Minimising the dealing with travel arrangements (visa, insurance etc.)

( ) Convenience- Please specify: Other-Please specify:

6. Focus on your last mountaineering vacation. What was the approximate length of booking time before travelling?
( ) More than a year
( ) Within 6-12 months before travel
( ) Within 3-6 months before travel
( ) Within 3 months before travel
( ) Don't remember

7. Please provide any comments reflecting your views towards the product offer of mountaineering holidays by Slovak outbound travel agencies/tour-operators in regards to the following aspects:

Offer range of holiday destinations:

Offer range of destination facilities and services:

Offer range of mountaineering activities available:

Offer range of other activities available at the destination:

Transport to the destination:

Facilitation of formal arrangements connected with international travel, such as visa etc.:

The charged price range for mountaineering holidays:

Guides: 
8. If you wish, provide any other comments on the mountaineering holiday offer of Slovak tourism supply side:

9. Kindly state your age:
( ) $18-25$
( ) $26-30$
() $31-40$
() $41-50$
() $51-65$
( ) Over 60

10. Please indicate your average monthly income:
( ) $250-330$ EUR
( ) 330 - 550 EUR
( ) 550 - 830 EUR
() 830 EUR and more
( ) Not applicable

11. Please state your current employment activity:

12. Please state your highest education level: 